\title{
Compositions of the Neoproterozoic basement rocks in Northern Vietnam and its tectonic significance
}

\author{
Xueyao Zhou ${ }^{1,2}$, Jin-HAi Yu ${ }^{2}$, DinhLUyen NGUYEN ${ }^{2,3}$
}

${ }^{1}$ Anhui Jianzhu University, Hefei, Anhui 230022, China

${ }^{2}$ State Key Laboratory for Mineral Deposits Research, School of Earth Sciences and Engineering, Nanjing University, Nanjing 210046, China

${ }^{3} \mathrm{Ha}$ Noi University of Mining and Geology, Ha Noi, Vietnam

Northern Vietnam is located at the tectonic junction of the Yangtze, Cathaysia, and Indochina blocks. However, the lack of a systematic understanding of the basement rocks in this area has led to a debate about its tectonic affinity. In this study, we present integrated bulk geochemical and zircon U$\mathrm{Pb}-\mathrm{Hf}$ isotopic data for the basement rocks in the Song Chay and Nam Co belts, which are located to the northeast of the Song Chay fault in NE Vietnam and Song Ma fault in NW Vietnam, respectively. Zircon U-Pb dating results suggest that the Thac Ba Formation in the Song Chay belt was deposited in the late Neoproterozoic $(<607-592 \mathrm{Ma})$, and the Nam Co Formation in Nam Co belt is of middle-late Neoproterozoic age $(<821-721 \mathrm{Ma})$. The sedimentary rocks from these Neoproterozoic strata are characterized by numerous Neoproterozoic (900-800 Ma) detrital materials. Detrital zircon age distribution and Hf-isotope compositions of them are similar with those of the Neoproterozoic sedimentary rocks in the southern Yangtze Block, but are different from those in the Cathaysia and Indochina blocks. Both zircon U-Pb-Hf isotopic and whole-rock geochemical data suggest that the source materials of these Neoproterozoic strata in the northern Vietnam were dominated by felsic rocks with minor mafic materials, and the detrital materials were mainly derived from the Yangtze Block.

Integration of our data with other lines of evidence suggests that the Precambrian basement under study areas in Northern Vietnam is the part of the Yangtze Block. Thus, the boundary between the South China and Indochina blocks should be to the southwest of the Nam Co belt, and is most likely the Song Ma fault. 